\title{
Article
}

\section{Characteristics Of Stunting Children With Background History Of Family Demography And Maternal Reproductive In Pasaman And Pasaman Barat District, West Sumatera}

\author{
Dr. dr. Masrul, M.Sc., SpGK \\ ${ }^{1}$ Department of Nutrition, Faculty of Medicine, Andalas University
}

\section{SUBMISSION TRACK}

Recieved:

Final Revision:

Available Online:

\section{KEYWORDS}

Stunting, family demographics, maternal reproductive

CORRESPONDENCE

Phone: $\operatorname{xxxxxxxxxxx}$

E-mail:

\section{A B $\quad \mathbf{S}$ T $\mathbf{R}$ A $\mathbf{C}$ T}

About a quarter of children under five years old worldwide are affected by stunting. There are 7.6 million (37\%) Indonesian children suffering from stunting and the rate of stunting in West Sumatra is above the national rate which is $46.1 \%$. That number shows that many of children need more attention, because they don't grow well. The purpose of this study was to determine the characteristics of stunting children based on the background history of family demographic and maternal reproductive. Data was obtained by interviewing respondents and data were analyzed using statistical tests. Respondents consisted of stunting children and normal children in Pasaman District and West Pasaman District. It is known that the incidence of stunting associated with respondent demographics and history of birth which is the length of born infant, education of head of the family, form of the core family, social and economic ..

\section{INTRODUCTION}

Approximately one quarter of children under five years in the whole world is affected by stunting. Stunting is the effect of a systemic condition with chronic malnutrition. Childhood stunting can develop during the first two years of life and is largely caused by nutritional deficiencies and infectious diseases (Black et al., 2013). In 2014, there were an estimated 159 million stunting children who almost all lived in low-income countries (Black et al., 2013, Semba et al., 2016, UNICEF / World Health
Organization / World Bank Group, 2015). Data from the Indonesian Ministry of Health reports that there were 7.6 million (37\%) Indonesian children suffering from stunting. The number of stunting patients in West Sumatra is above the national figure of 46.1\%. That number shows that many children need more attention, because they don't grow well.

The factors that cause stunting are determined by layered determinants (direct, intermediate, and underlying determinants) 
and determinant groups. In this study focused on underlying determinants. Things that cover the basic determinants are maternal characteristics (age, physical health, psychosocial health, and nutritional status), household characteristics (household health, religion, social level, parental education, household regulations), and regional characteristics (country, location of residence, food production, food distribution, and population growth) (Fenske N. et al., 2013).

Stunting has long-term effects such as decreased survival, impaired cognitive and motor development, decreased economic productivity, and a higher chance of living in poverty in adulthood (Black et al., 2013, Grantham-McGregor et al., 2007) .

The purpose of this study was to determine the characteristics of stunting children with family demographic background and maternal reproduction at the locus of West Pasaman Regency and Pasaman District from 100 regencies / cities that were intervened in Indonesia. This study is one part of a large study through a collaboration between the Directorate of Community Nutrition of the Ministry of Health of the Republic of Indonesia and the Andalas University Medical School in 2018 regarding stunting in West Sumatra with KN. 01.01 / 2/1302/2018 and 2655 / UN.16.2 / TU / 2018 .

\section{METHODS}

1. Sample population

The target population in this study were all children aged 0-3 years in Pasaman and Pasaman and West Pasaman. The subjects in this study were all cases and controls chosen with a case and control ratio of 1: 1. Cases are toddlers aged 0-3 years with z-score TB / $\mathrm{U} \leq-2 \mathrm{SD}$ index, while controls are toddlers aged 0-3 years with zscore TB / U -2SD index up to $+2 \mathrm{SD}$. Respondents in this study were selected toddlers as subjects of the study. The inclusion criteria in this study were toddlers aged 0-3 years who lived and settled in Pasaman and West Pasaman districts, were neither sick nor disabled and lived with both parents, and had a Towards Healthy Card (KMS). The number of subjects in each group was 100 subjects which were calculated using the formula for the case control sample size and added $10 \%$ in anticipation of dropping out.

The dependent variable in this study was stunting, while the independent variables were birth length, family economic status, education level and parent's height. Data collected included subject identities, current toddler height, toddler birth length, toddler and mother height, parent education, parent jobs, total family income, and the number of family members. Birth length is body length when newborns are obtained from data in KMS, then the data is converted into the index value of $\mathrm{z}$-score TB / $\mathrm{U}$ and if the result is $\leq-2$ SD then it is categorized as short birth length, and if the result is> -2SD is categorized as a short body birth length.

2. Data analysis

The data obtained was tested by various appropriate statistical tests.

\section{RESULTS AND DISCUSSION}

1. Characteristics of Respondents Characteristics of respondents in this study can be known as follows.

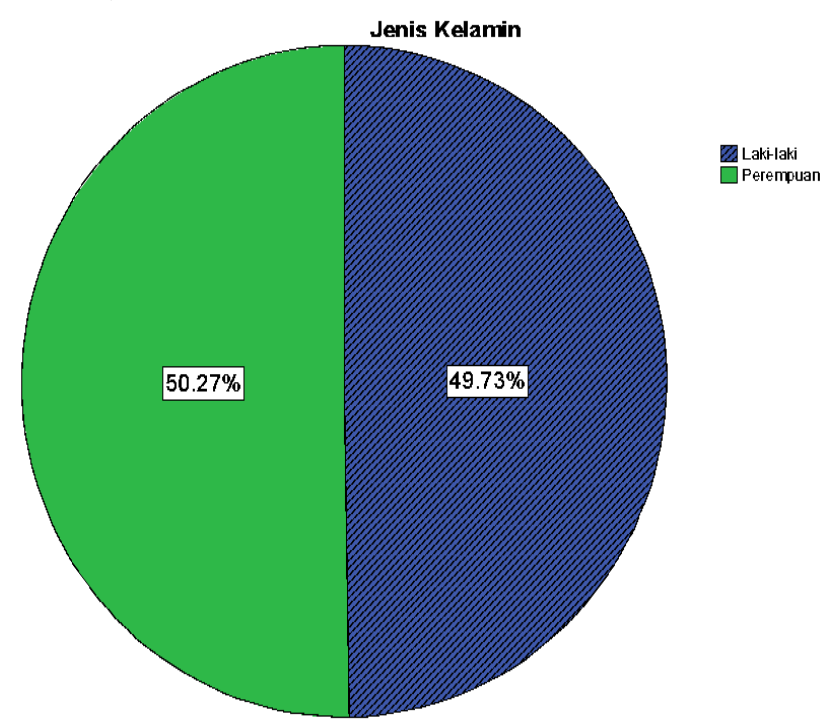

Figure 1. The picture of the sex of the child

Figure 1 shows that more than half of the respondents $(50.27 \%)$ were male and less than half of the respondents $(49.73 \%)$ 
were female. Other respondent characteristics can be seen as follows.

Table 1. Demographic characteristics of respondents

\begin{tabular}{|c|c|c|c|}
\hline \multirow[b]{2}{*}{ Variable } & \multicolumn{2}{|c|}{ Nutritional Status } & \multirow[b]{2}{*}{ p value } \\
\hline & $\begin{array}{c}\text { Stunting } \\
(\mathrm{n}=94)\end{array}$ & $\begin{array}{l}\text { Normal } \\
(\mathrm{n}=91)\end{array}$ & \\
\hline \multicolumn{4}{|c|}{ Characteristics of children } \\
\hline $\begin{array}{l}\text { Age of child } \\
\text { (month), } \\
\text { mean } \pm \text { SD }\end{array}$ & $\begin{array}{c}23.97 \pm \\
6.74\end{array}$ & $\begin{array}{c}24.44 \pm \\
6.95\end{array}$ & 0.640 \\
\hline $\begin{array}{l}\text { Birth order } \\
\text { of child } \\
\text { mean } \pm \mathrm{SD}\end{array}$ & $2.56 \pm 1.54$ & $2.60 \pm 1.44$ & 0.854 \\
\hline \multicolumn{4}{|c|}{ Demographic characteristics of the family } \\
\hline $\begin{array}{l}\text { Education of } \\
\text { the head of } \\
\text { the family, } \mathrm{f} \\
(\%)\end{array}$ & & & \\
\hline $\begin{array}{l}\text { Never } \\
\text { attended } \\
\text { school }\end{array}$ & $15(16.0)$ & $5(5.5)$ & $0.003 *$ \\
\hline $\begin{array}{l}\text { Did not finish } \\
\text { elementary } \\
\text { school }\end{array}$ & $19(20.2)$ & $6(6.6)$ & \\
\hline $\begin{array}{l}\text { graduated } \\
\text { elementary } \\
\text { school }\end{array}$ & $28(29.8)$ & $31(34.1)$ & \\
\hline $\begin{array}{l}\text { graduated } \\
\text { junior high } \\
\text { school }\end{array}$ & $13(13.8)$ & $18(19.8)$ & \\
\hline $\begin{array}{l}\text { Graduated } \\
\text { from High } \\
\text { School }\end{array}$ & $16(17.0)$ & $30(33.0)$ & \\
\hline $\begin{array}{l}\text { Completed } \\
\text { Diploma / } \\
\text { Bachelor }\end{array}$ & $3(3.2)$ & $1(1.1)$ & \\
\hline Degree & & & His \\
\hline $\begin{array}{l}\text { Employment } \\
\text { of head of } \\
\text { family }\end{array}$ & & & \\
\hline $\begin{array}{l}\text { Government } \\
\text { employee }\end{array}$ & $1(1.1)$ & 0 & $\mathrm{~N} / \mathrm{A}$ \\
\hline $\begin{array}{l}\text { Private } \\
\text { employee }\end{array}$ & 0 & $2(2.2)$ & \\
\hline Honorary & $1(1.1)$ & $3(3.3)$ & \\
\hline Self Employed & $15(16.0)$ & $24(26.4)$ & \\
\hline Workers / & $11(11.7)$ & $17(18.7)$ & \\
\hline $\begin{array}{l}\text { laborers / } \\
\text { servants }\end{array}$ & & & \\
\hline Dthers & $66(70.2)$ & $45(49.5)$ & \\
\hline $\begin{array}{l}\text { Income per } \\
\text { month (Rp), } \\
\text { mean } \pm \mathrm{SD}\end{array}$ & $\begin{array}{c}717375 \pm \\
144713\end{array}$ & $\begin{array}{c}1417349 \pm \\
202534\end{array}$ & 0.081 \\
\hline
\end{tabular}

Table 2. Characteristics of respondents based on family members

\begin{tabular}{|c|c|c|c|}
\hline \multirow[b]{2}{*}{ Variables } & \multicolumn{2}{|c|}{ Nutritional status } & \multirow[b]{2}{*}{$p$ value } \\
\hline & $\begin{array}{c}\text { Stunting } \\
(\mathrm{n}=94)\end{array}$ & $\begin{array}{l}\text { Normal } \\
(\mathbf{n}=91)\end{array}$ & \\
\hline $\begin{array}{l}\text { Number of } \\
\text { family } \\
\text { members, } \\
\text { mean } \pm S D\end{array}$ & $\begin{array}{c}4.78 \pm \\
1.61\end{array}$ & $\begin{array}{c}5.07 \pm \\
1.73\end{array}$ & 0.240 \\
\hline $\begin{array}{l}\text { Living } \\
\text { children } \\
\text { mean } \pm \mathrm{SD} \\
\text { Mother stay } \\
\text { home alone }\end{array}$ & $\begin{array}{c}2.64 \pm \\
1.57\end{array}$ & $\begin{array}{c}2.42 \pm \\
1.17\end{array}$ & 0.281 \\
\hline Yes & 46 (48.9) & $38(41.8)$ & 0405 \\
\hline $\begin{array}{l}\text { No } \\
\text { Additional } \\
\text { family } \\
\text { members }\end{array}$ & $48(51.1)$ & $53(58.2)$ & \\
\hline $\begin{array}{l}\text { Yes } \\
\text { (extended } \\
\text { family) }\end{array}$ & $20(21.3)$ & $35(38.5)$ & $0.017 *$ \\
\hline $\begin{array}{l}\text { No (main } \\
\text { family) }\end{array}$ & $74(78.7)$ & $56(61.5)$ & \\
\hline
\end{tabular}

Table 1 and Table 2 showed that there is a relationship between education and family members with the incidence of stunting $(\mathrm{p}$ $<0.05)$. But there was no correlation between age, birth weight, birth order of child, occupation of the head of the family, monthly income, number of family members, living children and mothers living at home with the incidence of stunting ( $p>0.05)$.

2. Pregnancy History and Birth

History of pregnancy and birth can be seen in table 3 below.

Table 3. Maternal reproductive history









$* \mathrm{p}<0.05$, significant

Table 3 it was found that there was a relationship between the place of antenatal care, history of TT immunization, childbirth process and place of birth with the incidence of stunting ( $\mathrm{p}<0.05)$. But there was no relationship between parity, history of miscarriage, number of miscarriages, history of stillbirth, possession of KIA books, SEZ, birth attendants, acquisition of PMT, ANC services, obtaining $\mathrm{Fe}$ tablets, $\mathrm{Fe}$ tablets taken, places to get $\mathrm{Fe}$ tablets, history of premature delivery, number of deliveries premature, length of stay, active smoker family members, active smoker family members, number of cigarettes and exposure to cigarette smoke with the incidence of stunting ( $\mathrm{p}>0.05)$.

\section{Characteristics of Respondents}

The level of education of the family heads of stunting children is not more school than normal children. Based on the level of family education is better in normal children compared to stunting children. The education level of the family head is related to the ability of parents to receive information about nutrition and health. The higher the level of education of the family head, the easier it is to receive information so that children's nutritional needs are achieved (Masrul, 2005).

The family of stunting children consists mainly of nuclear families compared to families of normal children who have more additional family members. The presence of family members other than the main family influences child care and supervision of nutrition needed by the child. If the child's parents are not at home, then the one who supervises the child is that extra family so that the child's nutritional needs can be met (Jellife, 1989; Masrul, 2005)

Socio-economic conditions are the root cause of stunting (WHO - UNICEF, 2000; Jellife DB, 1989 ) Based on this study the work of the head of the family, monthly income, number of family members, living children and mothers living in their own homes there is no relationship with the incidence of stunting. Even though it does not have a significant relationship, the work of the head of the family and low monthly income is usually the family that consumes cheaper food and less diverse foods. While parents who have high income choose to buy more expensive and varied foods. However, this does not rule out the possibility that parents with low income can choose nutritious foods even at low prices (Masrul, 2005).

\section{Pregnancy and Childbirth History}

From the data of birth weight it was found that there was no statistical difference between normal children and stunting children. But based on body length at birth they differ significantly. Stunting children are shorter than $5.38 \mathrm{~cm}$ at birth compared to normal children. Normally, the body length born in Indonesia is around $48-52 \mathrm{~cm}$ (Riskesdas, 2007/2010). The process of occurrence has begun in the mother's womb.

From the history of the mother's data, pregnancy and childbirth are almost not too different except the level of ownership of the $\mathrm{MCH}$ books (Mother and Child Card) is more owned by mothers with stunting children than normal. However, there was more history of SEZ mothers in stunting children during pregnancy $(19.4 \%)$ than mothers with normal children (11.5\%). Childbirth helpers are health workers, but more normal children are helped by obstetricians. The history of mothers who received $\mathrm{Fe}$ tablets was almost the same from both groups (Soki, 2012; Reskesdas, 2013).

The mother of a stunting child gets more tetanus immunization compared to a mother of a normal child.

\section{CONCLUSION}

The process of stunting is related to the demographic factors of the respondent and birth history, which were the length of birth of the child, education of the head of the family, form of the main family, and socioeconomic. Stunting has occurred since the baby in the womb. The history of SEZ mothers is more likely in the mother of a stunting child when she is pregnant rather than mother whose child is normal. 



\section{REFERENCES}

Bhutta, Z.A., Das, J.K., Rizvi, A., et al., 2013. Evidence-based interventions for improvement of maternal and child nutrition: what can be done and at what cost? Lancet 382, 452-477.

Black R.E., Victora C.G., Walker S.P. Maternal and child undernutrition and overweight in lowincome and middle-income countries. Lancet. 2013;382:427-451.

de Onis M., Onyango A., Borghi E. Worldwide implementation of the WHO Child Growth Standards. Public Health Nutr. 2012;15:1603-1610.

Engle P.L,Menon P., Haddad L. 1995. Care and Nutrition: Concepts and Measurement International Food Policy Reseacrh.

Fenske N, Burns J, Hothorn T, Rehfuess E.A. 2013. Understanding Child Stunting in India: A Comprehensive Analysis of Socio-Economic, Nutritional and Environmental Determinants Using Additive Quantile Regression. Plos One 8 (11): 1 - 16.

Ghosh S, Suri D, Uauy R. Assessment of protein adequacy in developing countries: quality matters. Br J Nutr 2012;108(Suppl 2):S77-87.

Henmughan HB, Mc Gregor SG. 2003. Refondasi Pertumbuhan Usia. Gizi Kesehatan Masyarakat EGC. Hal 206 - 307.

Henmighan HB, Mc Gregor GG. 2005. Pemberian ASI dan Pengasuh Terhadap Tumbuh Kembang Anak Dalam: Gizi Kesehatan Masyarakat. EGC. Hal: 300 - 310.

Jellife D.B. 1989. Community Nutrional Assessment. Oxford University Press. New York.

Jonssan U. 1983. Nutrition and The United Nations Convention and The Rights of The Child Occasional Papers. Child Right Series No.5.

Kemenkes. 2007. Reset Kesehatan

Kemenkes. 2010. Riset Kesehatan

Laplante M, Sabatini DM. mTOR signaling in growth control and dis- ease. Cell 2012;149:27493.

Masrul 2005. Kajian Peranan Sumber Daya Pengasuhan Terhadap Tumbuh Kembang Bayi Usia 6 - 12 bulan Pada Keluarga Etnik Minangkabau di Pedesaan Provinsi Sumatera Barat. Disertasi: Program Pasca Sarjana Universitas Airlangga.

Murray C.J. Shifting to sustainable development goals-implications for global health. N. Engl. J. Med. 2015;373:1390-1393.

Nuss ET, Tanumihardjo SA. Quality protein maize for Africa: closing the protein inadequacy gap in vulnerable populations. Adv Nutr 2011; 2:217-24.

Semba R.D. Nutrition and development: a historical perspective. In: Semba R.D., Bloem M.W., editors. Nutrition and Health in Developing Countries. second ed. Humana Press; Totowa, NJ: 2008. pp. 1-31. 
Semba RD, Shardell M, Sakr Ashour FA, Moaddel R, Trehan I, Maleta KM, Ordiz MI, Kraemer K, Khadeer MA, Ferrucci L, et al. Child stunting is associated with low circulating essential amino acids. EBioMedicine 2016;6:246-52.

Soetjimipsil, Ranuh. 1998. Strategi Kelangsungan Hidup Anak Dalam; Tumbuh Kembang Anak. Hal: $127-140$.

UNICEF/World Health Organization/World Bank Group . United Nations Children's Fund, World Health Organization, and World Bank Group. 2015. Levels and Trends in Child Malnutrition: Key Findings of the 2015 Edition. ([ http://www.who.int/nutgrowthdb/jme brochure2015.pdf?ua=1]

Van Dam TJ, Zwartkruis FJ, Bos JL, Snel B. Evolution of the TOR pathway. J Mol Evol 2011;73:209-20.

Verley K.G, Mayer D.R. 2011. Early Child Growt; How Nutrition and Infection Interact. Maternal Child Nutrition Journal Vol 7. 3 Oktober 2011. 